spared in the execution of the inspections. But at the same time I should be pleased to observe, that the American authorities by looking after the declarations belonging to each consignment from a Dutchman should ascertain for themselves the origin of the shipment in question.

"It may be possible, that some copy is lost from a box or bale, but this will not be the case with all copies of the shipment, and anyhow the original certificate belonging to the whole shipment must be present.

"I always will be obliged for the communication of all contravention of the rules mentioned above.

"Might some alteration be settled either in the text of the copies or in that of the certificate itself. I hope to inform you at an early date."

With many kind regards,

Yours very truly,

J. Ritsema Bos.

\title{
NOTE ON THERONIA FULVESCENS
}

By J. M. Aldrich, Moscow, Ida.

A reperusal of some back numbers of the JournaL leads me to offer a belated note on the above species as a parasite of Neophasia menapia, the white butterfly of western pine and fir. Fiske and Thompson (Journal, 2: 455) mention fulvescens as "the most common parasite of the gypsy moth native to America," but add that it has been recorded both as primary and secondary in some of its host relations. At the time of the publication of that item I intended to add the following, but postponed action until it was for the time forgotten.

Neophasia menapia was for some years after its discovery an excessively rare butterfly, only a few specimens finding their way into collections. Later it was found once or twice in swarms in the western forests, and again it seemed to disappear. In this period I came to Idaho in 1893. Two years later it began to be noticeably abundant near Moscow, Idaho, and in 1896-7-8 it caused much loss in the forests of the northwest by completely defoliating pine and fir timber in considerable areas, while in all the intervening forests it was very abundant also. At this point Theronia fulvescens attracted my attention as a parasite of the butterfly, material reared by me from pupæ of the latter being determined by the Bureau of Entomology. The parasite reached its maximun in 1898, at which time it swarmed in the woods in late summer in incredible numbers. In places the air 
was full of them, and they made a very perceptible humming sound like a swarm of bees. At the University of Idaho, about seven miles from the forest, it was abundant, and on one occasion I collected 40 specimens by picking them off the walls of the administration building while going once round it - and this seven miles from where any of them matured.

The next spring the extermination of menapia seemed complete all over the northwest. In ten years afterward I think I saw only one specimen alive. Only in the last two or three years is it "coming back," and we seem to be at the beginning of another cycle of abundance.

I secured no other parasite of menapia, and fulvescens was present in millions, from which it would appear that the previous fluctuations. of menapia may have been caused in the same way as the one described.

On account of the burning of my notes in a university fire, I am obliged to trust to memory, and it is possible that the year of extermination may have been 1899 .

The parasite died out at once, and was not seen again for several years. It may have other hosts here, but no other caterpillar is abnormally abundant in our forests, so the numbers of the parasite of necessity fell at once almost to zero, on the disappearance of the principal host. I have never seen another case so striking of the effect of parasitism on both host and parasite. I have made no observations on fulvescens as a secondary parasite.

\title{
SOME ECONOMIC METHODS A HUNDRED YEARS OLD
}

\author{
By Harry B. Weiss, New Brunswick, N. J.
}

In going over some old works on entomology, I was impressed by the similarity of some of the methods in use a hundred years ago and those of today. By this, I do not mean to imply that we have not gone forward in that length of time, but, rather that in many cases, we are still following the basic principles of the old methods.

When our grandfathers were troubled by wire worms, it was customary to bury beneath the soil, slices of potatoes stuck on skewers. These were pulled up every day and the larvæ thereon killed. These baits of course were stuck alongside of the infested plants. For fields overrun with injurious larvæ, it was recommended that the infested land be ploughed up and a flock of ducks or other poultry or a drove of pigs turned in, and drenching a field with stable urine was supposed to kill all grubs in addition to acting as a fertilizer. With- 


\section{$2 \mathrm{BHL}$ Biodiversity Heritage Library}

Aldrich, John Merton. 1912. "Note on Theronia fulvescens." Journal of economic entomology 5, 87-88.

View This Item Online: https://www.biodiversitylibrary.org/item/37187

Permalink: https://www.biodiversitylibrary.org/partpdf/33043

\section{Holding Institution}

New York Botanical Garden, LuEsther T. Mertz Library

\section{Sponsored by}

The LuEsther T Mertz Library, the New York Botanical Garden

\section{Copyright \& Reuse}

Copyright Status: NOT_IN_COPYRIGHT

This document was created from content at the Biodiversity Heritage Library, the world's largest open access digital library for biodiversity literature and archives. Visit BHL at https://www.biodiversitylibrary.org. 